\section{ЛІТЕРАТУРА}

1. Крупський I. Національно-патріотична журналістика України (друга половина XIX. - перша чверть ХХ ст.). - Львів: Світ, 1995. - 184 с.

2. Моніторинг та інформаційне моделювання засобів масової інформації: колективна монографія / [В. В. Різун, В. Ф. Іванов, Н. П. Шумарова та ін.; за ред. В. В. Різуна; упоряд. Т. В. Скотникова]. - К.: Київський університет, 2007. - С 11.

3. Словник журналіста: терміни, мас-медіа, постаті / за ред. Ю. Бідзілі. - Ужгород: Закарпаття, 2007. - 224 с.

4. Хімяк О. Українська преса на Американському континенті (кінець XIX - початок XX СТ.) // Українська національна ідея: реалії та перспективи розвитку, випуск 24, 2012. - C. $27-31$

5. Lasswell H. The Structure and Function of Communication in Society // The Communication of Ideas. - New York: Institute for Religious and Social Studies, 1948. - P. 37.

\section{REFERENCES}

1. Krupskyi, I. (1995). Natsionalno-patriotychna zhurnalistyka Ukrainy (druha polovyna XIX. - persha chvert $X X$ st.) [The National-Patriotic journalism (the second half of XIX - first quarter of XX century)]. Lviv: Svit, 184 p. [in Ukrainian].

2. Rizun, V. V., Ivanov, V. F., Shumarova, N. P. et al; (Ed.).V. V. Rizun (2007). Monitorynh ta informatsiine modeliuvannia zasobiv masovoi informatsii [Monitoring and information modeling media]. Kyiv: Kyivskyi universytet, p. 11. [in Ukrainian].

3. Bidzili, Yu. (2007). Slovnyk zhurnalista: terminy, mas-media, postati [Dictionary of the journalist: the timing, the media, personalities]. Uzhhorod: Zakar pattia, $224 \mathrm{p}$. [in Ukrainian].

4. Khimiak, O. (2012). Ukrainska presa na Amerykanskomu kontynenti (kinets XIX - pochatok XX st.) [English press on the American continent (end of 19th beginning of 20 th century)]. Ukrainska natsionalna ideia: realii ta perspektyvy rozvytku, Vol. 24, pp. 27-31. [in Ukrainian].

5. Lasswell, H. (1948). The Structure and Function of Communication in Society. The Communication of Ideas. New York: Institute for Religious and Social Studies, p. 37. [in English].

Стаття надійшла до редакції 16.11.2018

УДК 373.2.015.31:78

DOI:

Зоряна Жигаль, кандидат педагогічних наук, доцент кафедри музичного мистецтва факультету культури і мистецтв Львівського національного університету імені Івана Франка

\title{
ДОШКІЛЬНЕ МУЗИЧНЕ ВИХОВАННЯ: ОСОБИСТІСНО ОРІЄНТОВАНИЙ ПІДХІД
}

У статті висвітлено теоретичний аспект особистісно орієнтованого дошкільного музичного виховання. Проаналізовано підходи зарубіжних вчених-педагогів, зокрема М. Монтессорі, Р. Штайнера, К. Орфа щодо особистісно орієнтованих технологій навчання $і$ виховання, а також можливості застосування ї у сучасному дошкільному музичному вихованні. Музичне виховання дошкільників розглядається як важливий засіб формування їхньої особистості і всебічного розвитку. Висвітлені принципи та особливості особистісно орієнтованого дочкільного музичного навчання та виховання.

Ключові слова: особистісно орієнтоване дошкільне музичне виховання; зарубіжні музично-педагогічні системи; особистісно орієнтована технологія.

Лim. 6.

Zoryana Zhyhal, Ph.D.(Pedagogy), Associate Professor of the Music Art Department Faculty of Culture and Arts Lviv Ivan Franko National University

\section{PRESCHOOL MUSIC EDUCATION: THE PERSONALLY ORIENTED APPROACH}

The article deals with the theoretical aspect of personally oriented preschool musical education. The concept of personally oriented technologies is highlighted. The purpose of personally oriented technologies is considered, which is to maintain and develop the child's natural qualities, individual abilities; to assist in the development of its subjectivity, sociality, cultural identity, creative self-realization. The approaches of foreign scientists-teachers, in particular M. Montessori, R. Steiner, K. Orf on the person-oriented technologies of education and upbringing, as well as the possibility of using them in modern preschool music education, are analyzed. Music education for preschoolers is considered an important means of forming their personality and comprehensive development. The principles and features of personally oriented preschool musical education are highlighted. It is precisely in the preschool age that the foundations of musical education and aesthetic attitude towards life are laid. It is determined that the use of personally oriented technologies in the system of pre-school music education contributes to the development of emotional sensitivity and musical abilities of children, as well as the perception of music as a 
specific language of human communication. The feature of preschool musical education is the creation of pedagogical conditions for the awakening and activation of creative impulses in children for the knowledge of the world of art. An important task of preschool musical education is the harmonious development of children in harmony with the surrounding world, which contributes to the formation of a self-confident personality.

Keywords: the personally oriented preschool musical education; the foreign musical-pedagogical systems; the personally oriented technology.

П остановка проблеми. Сучасне виховання неможливе без звернення до особистості. Пріоритетами сьогодні стають особистісна художньо-творча самореалізація дітей, на що спрямовуються i зміст, і технології виховання. Саме в дошкільному віці закладаються основи музичного виховання та естетичного відношення до життя. Особливістю дошкільного музичного виховання є створення педагогічних умов для пробудження та активізації в дітей творчих імпульсів для пізнання світу мистецтва. Суспільна потреба спонукає сучасних вихователів, педагогів-музикантів та науковців до пошуку нових ідей і технологій, до поширення та запровадження передового педагогічного досвіду. Саме тому наукову розвідку спрямовано на теоретичне обгрунтування особистісно орієнтованих технологій, які застосовуються в дошкільному музичному вихованні.

Аналіз останніх досліджень та публікацій. Психолого-педагогічні та дидактичні основи особистісно орієнтованого навчання досліджені вченими Г. Баллом, І. Бех, В. Загвязинським, С. Сисоєвою, О. Савченко, В. Кан-Каліком, O.М. Пєхотою, I. Підласим, І. Якиманською та ін. Проблему дошкільного музичного виховання досліджували такі вчені-педагоги, як О. Апраксіна, А. Бондаренко, А. Ветлугіна, Н. Комісарова.

Метою статті $\epsilon$ спроба висвітлити особливості застосування особистісно орієнтованої технології в умовах сучасного дошкільного музичного виховання.

Виклад основного матеріалу дослідження. До основоположників теоретичного індивідуального навчання насамперед слід віднести К. Ушинського, який першим серед учених практиків довів, що діти за соєю природою “уже індивідуальні” [6, 235]. На думку С.В. Бондаревської, особистісно орієнтована освіта "рефлексує природні особливості людини (здатність мислити, відчувати, діяти), iї якості як суб'єкта культури (свобода, гуманність, духовність, творчість). Розвиток даних якостей у єдності і складає результат названого типу навчання і виховання" $[1,18]$.

Призначення особистісно орієнтованих технологій полягає в тому, щоб підтримувати та розвивати природні якості дитини, індивідуальні здібності; допомагати у становленні $\dddot{1}$ суб'єктності, соціальності, культурної

Молодь і ринок №12 (167), 2018 ідентифікації, творчої самореалізації. Складному процесу розуміння малюками свого власного “ $Я$ ”, формуванню у них естетичних почуттів сприяє їхня активна участь у музичній діяльності у дошкільному навчально-виховному закладі. Інтегративні заняття з музичного мистецтва органічно поєднують в собі такі доступні хлопчикам і дівчаткам види музичної діяльності, як слухання мелодій, співи, рухи під музику та гру на інструментах.

Особистісно орієнтоване музичне виховання покликане забезпечити музичний розвиток та саморозвиток особистості дитини виходячи з його індивідуальних особливостей як суб'єкта пізнання. Музичне виховання дошкільників важливий засіб формування їхньої особистості і всебічного розвитку. Музика безпосередньо впливає на емоційну сферу дитини, стимулює пізнавальну активність, пробуджує творчі здібності. Педагогічний процес музичного виховання в дошкільному закладі повинен бути зорієнтований на виховання в дітей художніх потреб, інтересу до прекрасного в природі, в найближчому оточенні, у повсякденному побуті, що викликає у дітей різного віку емоційні відчуття $[2,7]$.

Діти не просто сприймають інформацію музичного керівника, а постійно співпрацюють 3 ним у режимі діалогу, висловлюють свої думки, діляться своїми почуттями, розумінням змісту музичного твору, колективно обговорюють його та аналізують, разом приходять до логічних $\mathrm{i}$ обгрунтованих висновків.

Під час бесіди про музичне явище чи окремий музичний твір немає правильних і неправильних відповідей. Є різні думки, точки зору, позиції і всі вони цінні, важливі. Музичний керівник приймає ïх усі, переконливо спрямовує у логічне, обгрунтоване, професійне русло. Він не примушує, а переконує дітей у прийнятті певної позиції, виконавської інтерпретації, характеру, темпу, динаміки і т. ін. Діти не просто засвоюють готові зразки, а усвідомлюють, яким чином вони отримані. Відбувається своєрідний обмін знаннями та досвідом музичного сприйняття, творчої діяльності. Діти у цьому процесі $\epsilon$ активними його учасниками, а музичний керівник шукає шляхи якомога ефективнішого особистісного музичного розвитку [5, 43]. Музика надає багаті можливості спілкування дорослого і 
дитини, створює основу для емоційного контакту між ними.

Як і кожна наукова технологія, особистісно орієнтована музично-освітня технологія опирається на ряд педагогічних принципів:

- системності, що вимагає розгляду музичноосвітнього процесу як цілісної системи послідовного набуття музичних знань, умінь і навичок;

- науковості, який спирається на закономірний зв'язок музичної педагогіки із філософією, фізіологією, психологією, загальною педагогікою, мистецтвознавством, педагогічною творчістю та iH;

- варіативності, що сприяє організації музичноосвітнього процесу на основі різноманітності музичного матеріалу, змісту, форм і методів роботи, вибір яких повинен здійснювати музичний керівник $з$ урахуванням поставленої мети та педагогічної підтримки кожної дитини;

- усвідомлення індивідуальності дитини, його самоцінності та неповторності, сукупності психічних, культурологічних і суто музичних рис;

- диференціаціїдітей наосновіприродовідповідності та особистісних відмінностей, пов'язаних із музичним досвідом, інтересами і здібностями кожної дитини;

- гуманізації змісту музичного навчання i виховання;

- історизму, що передбачає аналіз і включення до навчально-виховного процесу елементів історії музично-педагогічної освіти [3, 78].

Варто розглянути деякі аспекти зарубіжних педагогічних систем, основою яих є особистісно орієнтований підхід до дитини.

В основі методичної системи Марії Монтессорі лежить ідея про самостійну організацію життя дитини. Марія Монтессорі була переконана в тому, що виховання є вкрай індивідуальним і має своїм об'єктом, насамперед, життя окремої дитини, іiі саморозвиток. У своїх працях вона висунула вимогу про невтручання педагога у процес природного росту і духовного розвитку дитини. Завдання вихователя вона вбачала у створенні умов, які відповідали б потребам дитини, допомагали виявляти їі запити та сприяли самовихованню і самонавчанню. Новаторство системи Монтессорі найповніше виявилося в урахуванні сенситивних періодів розвитку дитини. На їі думку, кожна психологічна функція і здібність має оптимальний період свого формування і якщо цей час втрачено - відповідні нахили розвиваються важче і неефективно.

Процес музичноговиховання дитиниМ. Монтессорі поділяла на три етапи: перший - розвиток уваги до звуків, що оточують дитину; другий виявлення та закріплення метроритмічного сприймання музики; третій - формування мелодичного і гармонічного слуху.

Методика Марії Монтессорі це модель особистісно орієнтованого підходу до навчання і виховання, основними провідними положеннями якої є: вільне виховання; індивідуальність; спостереження за дитиною.

Особистісно орієнтованим технологіям властива гуманістична i психологічна спрямованість. До різновидів особисто орієнтованого навчання можна віднести вальдорфську педагогіку, що є втіленням ідей гуманістичної педагогіки. Ї̈̈ автор - німецький філософ Рудольф Штайнер поставив своїм завданням формування особистості як цілісної єдності.

Вальдорфська педагогіка не підтримує тезу про ранню інтелектуалізацію дитини та тенденцію починати інтенсивне навчання вже на 5 - 6 році життя, оскільки це вважається шкідливим для здоров'я дитини, забирає сили, необхідні для формування фізичного тіла.

Музичний елемент $\epsilon$ невіддільним від загального виховного процесу, який грунтується на ключовій тезі наслідувально - “поглинаючої” позиції дитини. Гра - головний розвивальний засіб виховання.

Мета музичного виховання в дитячому садку - підготувати дитину до сприйняття музики, показати їй як можна взаємодіяти 3 музикою, підготувати до активної подальшої музичної діяльності. Заняття включають в себе: живопис фарбами, малювання восковою крейдою, ліплення з воску, музикування, евритмію (синтез музики, руху, слова), драматичне мистецтво, мистецтво композиції, розповіді вихователем казок, віршів та історій, які супроводжуються ляльковими виставами тощо. Принципово важливим є використання у вальдорфському дитячому садку тільки “живої” музики та голосу. Магнітофони та інші музичні технічні засоби виключаються.

Головною метою виховного та навчального процесу - є сприяння розвитку природних здібностей дитини, надання можливостей для їх природного розкриття та зміцнення, розширення меж обдарованості дитини.

Моделлю особистісно орієнтованого підходу до дитини є музично-педагогічна система Карла Орфа, яка закладає хороші передумови для участі дітей урізноманітній музичній діяльності, оскільки грунтується не лише на інструментальному, а й ритмопластичному, танцювальному, співацькому музикуванні. Орієнтація на природні сили 
особистості, на елементарне музикування, на фольклор як першооснову музичної культури дають право розглядати дану музичну систему як особистісно орієнтовану.

На думку Карла Орфа, в ранньому дитинстві закономірно звертатися до мовних форм спілкування, які духовно відповідають раннім ступеням розвитку свідомості. Імена, заклички, співзвуччя, що римуються, загадки, заклинання, казки з їх магією, міфи - ось найкращий матеріал для раннього гуманістичного виховання. Тексти що передаються з покоління в покоління Карл Орф вважає такими, що не вимагають актуалізації і завжди діють на дітей безпосередньо і безвідмовно.

Малюки в дошкільному навчальному закладі буквально 3 першого дня музичних занять освоюють музичний інструментарій Карла Орфа. Вони носять такі ж назви, як звичайні інструменти: ксилофони, металофон і т.д., але помітно від них відрізняються. Карл Орф адаптував свої інструменти спеціально для дітей. На заняттях діти також танцюють легкі дитячі танці, перетворюють вірші в музичні п'єси, складають музику до казок, самі роблять шумові інструменти і грають в дитячому оркестрі.

Для того щоб розвинути у кожного музичні здібності, які в тій чи іншій мірі є абсолютно у всіх, треба дати можливість дитині бути діячем. Класичні методи навчання музики в дошкільних навчальних закладах часто бувають неефективними. Вихователь грає на фортепіано, а діти сидять і слухають не рухаючись. Якщо ж на першому занятті дати малятам в руки дитячі інструменти і попросити вистукувати метр пісні, ефект буде набагато кращим. Саме так і роблять педагоги, що працюють за системою Карла Орфа. Вони впевнені: чим більше різних інструментів, нехай навіть і саморобних, запропонувати дітям, тим краще.

Карл Орф був переконаний, що для дітей потрібна своя особлива музика, спеціально призначена для музикування на початковому етапі. Вона повинна бути доступна переживанню в дитячому віці і відповідати психологічному та емоційному стану дитини. Це не чиста музика, а музика яка нерозривно зв'язана з мовою і рухом: співати й одночасно пританцьовувати, вигукувати дражнилку і чим-небудь дзвеніти. Чергувати мову та спів для дітей так само природно, як просто гратися. Музика для дітей $є$ у всіх народів світу. Дитяча музика будь-якого народу генетично нероздільно пов'язана з промовою і рухом. Її Карл Орф назвав елементарною музикою і зробив основою своєї дидактичної праці “Шульверк”.
Отже, застосування елементів музичнопедагогічної системи Карла Орфа в дошкільному музичному вихованні сприяє гармонійному розвитку дітей, пробудженню їх творчого потенціалу.

На основі вищевикладеного можна виділити особливості особистісно-орієнтованого дошкільного музичного навчання і виховання:

- музично-освітній процес будується на основі діалогу дитини та музичного керівника, який спрямовано на спільне конструювання музичного заняття чи виховного заходу;

- засади особистісного музичного навчання i виховання складають індивідуальний підхід до дітей, врахування їх інтересів, здібностей;

- основою організації особистісно орієнтованого дошкільного музичного виховання $є$ творчість, актуалізація життєвого досвіду дитини;

- враховується індивідуальна вибірковість дитини щодо виду, змісту і форми музичної діяльності, а також прагнення самостійно використовувати отримані музичні знання, уміння і навички, в томучислі й поза навчально-виховним процесом [4, 113].

Висновки. Важливим завданням дошкільного музичного виховання $€$ гармонійний розвиток дітей у співзвучності з оточуючим світом, що сприяе становленню впевненої в собі особистості.

Використання особистісно орієнтованих технологій в системі дошкільного музичного виховання сприяють розвитку у дітей емоційної чутливості та музичних здібностей, а також сприйняттю музики як специфічної мови людського спілкування.

\section{ЛІТЕРАТУРА}

1. Бондаревськая Е.В. Смыслы и стратегия личностноориентованного воспитания / Е.В. Бондаревськая // Педагогика. №1. К., 2001. -С. 56-62.

2. Буряк O.I. Музичне виховання в системі оздоровчої роботи з дошкільниками:посібник / О.І. Буряк. Хмельницький, 2015. - 31 с.

3. Горбенко С.С. Історія гуманізації музичної освіти. Навчальний посібник / С.С. Горбенко - м. КамянецьПодільській: видавець ПП Зволейко Д.П., 2007. $348 \mathrm{c}$.

4. Жигаль 3. Особистісно орієнтований підхід в процесі навчання музичного мистецтва / З. Жигаль // Молодь і ринок. Дрогобич: Коло. - №9(92), 2012. C.111-115

5. Музичне виховання у дошкільному закладі: Збірник методичних матеріалів / Упор. І.А.Романюк. Тернопіль: Мандрівець, 2007. - 143 с.

6. Шепеленко Д.А. Эстетическое развитие личности и его роль в гуманизации школы / Д.А. Шепеленко // Збірник методичних матеріалів. - Новочеркасск: Издво НГМА, 1998. - С. 105-112 


\section{ОСОБЛИВОСТІІНТЕРПРЕТАЦЙ УКРАЇНСЬКОГО ПІСЕННОГОФОЛЬКЛОРУ ПРЕДСТАВНИКАМИ ЛЬВІВСЬКОЇ ВОКАЛЬНОЇ ШКОЛИ ДРУГОЇ ПОЛОВИНИ ХХ СТ.}

\begin{abstract}
REFERENCES
1. Bondarevskaya, E.V. (2001). Smysly y stratehyya lychnostno-oryentovannoho vospytanyya [Meanings and strategy of personality-oriented education]. Pedagogy. No.1, pp. 56-62. [in Russian].

2. Buryak, O. I. (2015). Muzychne vykhovannya $v$ systemi ozdorovchoyi roboty $z$ doshkilnykamy [Musical education in the system of health work with preschoolers]. Khmelnytsky, 31p. [in Ukrainian].

3. Horbenko, S. S. (2007). Istoriya humanizatsiyi muzychnoyi osvity [History of humanization of musical education]. Tutorial. Kamyanets-Podilskiy: PP Zvoleyko D.P. Publ., 348 p. [in Ukrainian].
\end{abstract}

4. Zhyhal, Z. (2012). Osobystisno oriyentovanyy pidkhid v protsesi navchannya muzychnoho mystetstva [Personally oriented approach in the process of learning music art ]. Youth and market. Monthly scientificpedagogical journal, Vol. 9 (92). Drogobych, pp.111-115. [in Ukrainian].

5. Romanyuk, I. A. (Ed.). (2007). Muzychne vykhovannya u doshkilnomu zakladi [Musical education in a preschool institution]. Collection of methodical materials. Ternopil: Mandrivets, 143 p. [in Ukrainian].

6. Shepelenko, D. A. (1998). Estetycheskoe razvytye lychnosty y eho rol v humanyzatsyy shkoly [Aesthetic development of the person and his role in the humanization of the school]. Collection of methodical materials. Novocherkassk: NHMA Publ., pp. 105-112. [in Russian].

Стаття надійшла до редакції 12.11.2018

УДК $784.9 “ 18-19 ”$

DOI:

Андрій Ковбасюк, кандидат мистецтвознавства, доцент кафедри музикознавства та хорового мистецтва факультету культури і мистецтв Львівського національного університету імені Івана Франка

\section{ОСОБЛИВОСТІІНТЕРПРЕТАЦЙ УКРАЇНСЬКОГОПСЕННОГОФОЛЬКЛОРУ ПРЕДСТАВНИКАМИЛЬВІВСЬКОЇ ВОКАЛЬНОЇ ШКОЛИ ДРУГОЇ ПОЛОВИНИ ХХ СТ.}

У статті розглядається творча виконавська діяльність співаків Львівської вокальної иколи другої половини ХХ століття. Розглянуто умови формування Львівської вокальної школи. Висвітлено поняття художньої інтерпретаиії вокалістів. Здійснено аналіз інтерпретацій українського пісенного фольклору представниками Львівської вокальної школи, зокрема П. Кармалюка, С. Дарчука, О. Врабеля, М. Байко, В. Ігнатенка, І. Кушплера. Доведено, щуо у вокальному мистецтві особистість виступає не тільки як виконавець, а і як інтерпретатор.

Ключові слова: пісенний фольклор; інтерпретація; вокальна школа.

Jim. 5.

Andriy Kovbasyuk, Ph.D.(Art Studies), Associate Professor of the Musicology and Choral Art Department Faculty of Culture and Arts Lviv Ivan Franko National University

\section{FEATURES OFTHE INTERPRETATIONS OFUKRAINIAN SONG FOLKLOR BY REPRESENTATIVES OF LVIV VOCAL SCHOOL OF THE SECOND HALF OF XX CENTURY}

The article deals with the creative activity of singers of the Lviv vocal school of the second half of the twentieth century. It was analyzed that the formation of the national school was under the direct influence of the leading European vocal schools. The conditions of Lviv vocal school formation are considered. The concept of artistic interpretation of vocalists is highlighted. Performing profile, vocal-technical capabilities of the vocal apparatus of the artist determine the selection of folk-material material, the specific methods and means of interpretation that will preserve and reveal the semantics of folklore. The singer interprets the work (folk-verse samples, in particular) depending on their own musical-performing style and the archetype of performing the person's thinking. The analysis of interpretations of Ukrainian folk songs by representatives of the Lviv vocal school, in particular P. Karmalyuk, E. Darchuk, O. Werbel, M. Bayko, V. Ihnatenko, I. Kushkler, has been analyzed. It is noted that the singularity of the interpretation of folk samples in the performing practice of singers of the Lviv vocal school is the installation on the academic style of singing. It is proved that in vocal art the person acts not only as an executor, but also as an interpreter. The folk repertoire of the representatives of the vocal art of the Western Ukrainian region appears as a national identity, the means of representing the national folk and professional (as a processing) vocal art on the European scale. The folk-eared samples of the performing practice of representatives of Lviv vocal school became the means of uniting with the spiritual essence of national consciousness, through the democratization of the repertoire, as a means of popularizing the most worthy models of professional vocal art in Ukraine.

Keywords: the song folklore; an interpretation; a vocal school.

$\Pi$ остановка проблеми. Безсумнівним джерелом збагачення знань про становлення вокального мистецтва на

теренах Галичини $є$ дослідження творчої спадщини виконавців, які зробили свій вагомий внесок в історію розвитку цього виду мистецтва. 